\title{
Analisa Tingkat Persepsi Konsumen Terhadap Faktor Penentu Penggunaan Sistem Pembayaran Elektronik Pada Tokopedia
}

\author{
Ekky Yohanes Gunawan ${ }^{1}$, Jessica ${ }^{2}$, Wilsen ${ }^{3}$, Johanes Fernandes Andry ${ }^{4}$ \\ Teknik Informatika, Universitas Bunda Mulia \\ jessicamega30@gmail.com ${ }^{1}$, ekky_yohanes@yahoo.com ${ }^{2}$, wilsen270897@gmail.com ${ }^{3}$, if andry@kreavindo.com ${ }^{4}$
}

\begin{abstract}
Article Info
Article history:

Received : 26-11-2018

Revised : 03-11-2018

Accepted 04-11-2018

\section{Keyword:}

Persepsi Konsumen,

Faktor Penentu,

Sistem Pembayaran Elektronik,

E-commerce,

Tokopedia.

ABSTRACT

Sistem Pembayaran Elektronik (SPE) sudah sangat berkembang dibeberapa negara maju seperti UK dan beberapa negara lain yang telah mengembangkan cashless society yang terbukti meningkatkan kualitas hidup dari setiap individu dengan kemudahan yang diberikan dalam sistem pembayaran. Namun hal ini berbanding terbalik dengan keadaan negara Indonesia, negara berkembang yang masih menerapkan sistem pembayaran dengan menggunakan uang. Dari 110 koresponden yang ikut turut serta dalam penelitian ini, kurang dari $40 \%$ jumlah koresponden yang menggunakan SPE. Hal ini berarti persepsi konsumen mengenai sistem pembayaran masih terpaku dengan yang konvensional. Sedangkan yang kita tau saat ini banyak e-commerce seperti tokopedia sudah menggunakan sistem pembayaran elektronik. Keamanan dan kepercayaan merupakan faktor penentu bagi pengguna terhadap penggunaan sistem pembayaran online.
\end{abstract}

\section{Pendahuluan}

Hari ini internet telah menjadi masalah besar di dunia bisnis. Internet memiliki banyak manfaat dalam melakukan bisnis [1]. Berkembangnya internet sangat perlu dalam berbagai aspek kehidupan, salah satunya dalam aspek dunia bisnis [2]. Pertumbuhan ekonomi dan pembangunan sangat mendorong kegiatan di dunia industri dan perdagangan sehingga mereka menjadi sangat berkembang, baik secara internasional maupun nasional [3]. Transaksi jual beli yang semula dilakukan secara manual, kini mulai berubah, yaitu proses beli dan jual yang bisa dilakukan kapan saja dan di mana saja [4]. Pembelian barang melalui dunia maya memberikan suatu hal yang baru dalam industri jual beli barang di Indonesia. Hal ini dikarenakan perkembangan teknologi yang semakin canggih, masyarakat yang dinamis dengan mobilitas tinggi, serta sifat masyarakat Indonesia yang cenderung gemar dengan pelayanan, kemudahan, kecepatan, dan akurat dalam melakukan sebuah transaksi [5].

Pada tahun 1990, awal keberadaan perdagangan elektronik (e-commerce) menyediakan cara unik dalam melakukan bisnis perdagangan ke dunia konsumen dan bisnis [6]. Ecommerce adalah transaksi bisnis dalam jaringan elektronik yaitu internet. Pada dunia maya, terdapat banyak situs yang mewadahi masyarakat untuk menjual produknya. Salah satunya adalah Tokopedia [7]. Definisi E-Commerce paling populer didasarkan pada perspektif online dari bisnis yang dilakukan. E-commerce menyediakan kemampuan untuk membeli dan menjual produk, informasi dan layanan di Internet dan lingkungan online lainnya [8].

Kunci sukses dalam Usaha Mikro, Kecil dan Menengah (UMKM) adalah tersedianya pasar yang jelas untuk produk yang akan mereka jual. Target pasar saat ini untuk membuka toko tidak harus di rumah atau di toko, tetapi membuka bisnis yang dapat dilakukan dengan membuka toko online atau ecommece dengan menggunakan internet sebagai media penghubung [9]. Oleh karena itu sangat jelas untuk menargetkan orang-orang yang memahami teknologi [10].

Sistem E-Commerce adalah bentuk kemajuan teknologi informasi yang membawa sejumlah perubahan, termasuk mengurangi biaya interaksi antara pembeli dan penjual, interaksi dapat dilakukan tanpa batasan waktu dan tempat, memfasilitasi promosi, peluang untuk memperluas target pasar tanpa harus untuk menghabiskan modal besar dan investasi, transparansi bisnis dan kemudahan dalam memberikan layanan kepada konsumen atau pelanggan [11]. Oleh karena itu, kebutuhan utama dalam desain E-Commerce adalah sarana penting untuk memperluas informasi tentang berbagai produk dan memperluas area pasar dengan tujuan mencapai keunggulan kompetitif dan daya saing global [12]. 
Sejumlah perubahan signifikan dalam bentuk digitalisasi, mobilitas modal dan liberalisasi informasi di bidang bisnis [13]. Konsumen dapat melakukan transaksi tanpa batasan tempat dan waktu, serta respon terhadap informasi saat ini [14]. Mekanisme dalam proses transaksi bisnis semua dapat dilakukan secara online sehingga memudahkan konsumen untuk memproses pembayaran mereka di rumah dan di luar negeri. Kemudahan dalam melakukan transaksi domestik dan asing dengan biaya yang relatif lebih efektif, dan membuatnya lebih mudah untuk membangun kemitraan bisnis yang sejalan dengan kebutuhan [15] [16].

Berdasarkan data dari Asosiasi Kartu Kredit Indonesia (2013), sistem pembayaran yang paling umum digunakan dalam transaksi e-commerce di Indonesia adalah Transfer Bank (57\%), Cash on Delivery (28\%), Kartu Kredit (7\%) dan lainnya (8\%). Berdasarkan data ini diketahui bahwa sistem pembayaran yang paling banyak digunakan di Indonesia adalah Transfer Bank [17].

Artikel ini akan membahas faktor penentu penggunaan sistem pembayaran elektronik terutama pada platform tokopedia. Kepercayaan dan keamanan sistem pembayaran elektronik dapat melampaui kepercayaan pengguna dari sistem lama [18].

\section{LANDASAN TEORI}

\section{A. Tokopedia}

Tokopedia pertama kali mendapatkan pendanaan awal dari PT Indonusa Dwitama pada tahun 2009. Kemudian Tokopedia kembali mendapatkan suntikan dana dari pemodal ventura global seperti East Ventures (2010), Cyber Agent Ventures (2011), Netprice (2012), and SoftBank Ventures Korea (2013). Pada Oktober 2014, Tokopedia berhasil menjadi perusahaan teknologi pertama di Asia Tenggara, yang menerima investasi sebesar 100 juta USD atau sekitar Rp 1,2 triliun dari Sequoia Capital dan SoftBank Internet and Media Inc. Berkat dari mengembangkan bisnis online di Indonesia, PT Tokopedia berhasil mendapatkan penghargaan Marketeers of the Year 2014 untuk sektor E-Commerce pada acara Markplus Conference 2015 yang digelar oleh Markplus Inc tanggal 11 Desember 2014 [19]

\section{B. Sistem Pembayaran Elektronik}

Sistem pembayaran elektronik dapat didefinisikan sebagai semua pembayaran yang dilakukan kepada bisnis, bank, atau layanan publik dari masyarakat atau bisnis, dan dieksekusi melalui jaringan telekomunikasi atau jaringan elektronik menggunakan teknologi modern. Berdasarkan definisi ini, pembayaran elektronik yang dimaksud adalah pembayaran yang dilakukan sendiri oleh pelaku baik perorangan maupun bisnis, tanpa intervensi dari orang lain [20].

\section{Keamanan dan Kepercayaan pada Sistem Pembayaran Online.}

1. Keamanan

Variabel keamanan digunakan dalam mengidentifikasi tantangan yang terjadi pada sebuah sistem sistem pembayaran elektronik di Ghana. Faktor keamanan merupakan salah satu tantangan dalam pengembangan sistem pembayaran elektronik secara umum. Variabel keamanan juga digunakan dalam studi kasus ini. Melalui informasi yang diperoleh mengenai ekspektasi nasabah terhadap keamanan sistem uang elektronik, dapat ditentukan apakah tujuan pengembangan produk uang elektronik terkait dengan keamanan sudah sesuai dengan harapan nasabah. Selain itu, tingginya nilai dari variabel keamanan ini juga dapat menjadi indikator bahwa faktor keamanan merupakan salah satu tantangan yang dihadapi dalam pengembangan produk uang elektronik [20].

\section{Kepercayaan}

Theory of Reasoned Action (TRA) yaitu menganalisis proses psikologi yang mencerminkan dengan hubungan kepercayaan, tingkah laku, niat, dan kebiasaan. Teori ini menegaskan bahwa keinginan dalam melakukan suatu hal dipengaruhi oleh kebiasaan dan sikap pada seseorang dipengaruhi oleh kepercayaan tiap individu. Indikator variabel Customer Trust yaitu [21]:
1) Terpercaya
2) Informasi yang benar
3) Menjaga Komitmen
4) Menjaga mutu
5) Pelayanan yang sesuai keinginan pelanggan

\section{Confirmation Factor Analysis}

Confirmation Factor Analysis merupakan salah satu metode analisis multivariat yang dapat digunakan untuk mengkonfirmasikan apakah model pengukuran yang dibangun sesuai dengan yang dihipotesiskan. Dalam CFA, terdapat varabel laten dan variabel indikator. Variabel laten adalah variabel yang tidak dapat dibentuk dan dibangun secara langsung sedangkan variabel indikator adalah variabel yang dapat diamati dan diukur secara langsung [22].

Confirmation Factor Analysis merupakan salah satu dari dua pendekatan utama di dalam analisis faktor. Model CFA adalah metode dengan model dibentuk lebih dahulu, jumlah variabel laten ditentukan terlebih dahulu serta memerlukan identifikasi parameter. Pada First Order Confirmatory Factor Analysis suatu variabel laten diukur berdasarkan beberapa indikator yang dapat diukur secara langsung. Perbedaan First Order CFA dan Second Order CFA adalah pada Second Order CFA variabel laten tidak diukur langsung melalui indikator penilaian, melainkan melalui variabel laten yang lain [23].

\section{E. Composite reability}

Kriteria validity dan reliabilitas juga dapat dilihat dari nilai reliabilitas suatu konstruk. Composite reability mengukur suatu konstruk dapat dievaluasi dengan dua macam ukuran yaitu cronbach's alpha dan internal consistency. Konstruk dapat dinyatakan reliabel jika hasi; nilai composite reliability diatas 0,7 . Oleh karena itu dapat disimpulkan 
bahwa keseluruhan variabel penelitian dinyatakan memenuhi reliabilitas atau reliabel [24].

\section{Model Penelitian dan Hipotesis}

\section{A. Model Penelitian}

Model penelitian, berdasarkan hipotesis penelitian yang dikembangkan. Meskipun, beberapa faktor yang diidentifikasi dalam model ini telah digunakan dalam penelitian sebelumnya [25], model penelitian kami mengidentifikasi determinan baru yang dianggap penting bagi keamanan serta kepercayaan yang dirasakan konsumen. Seperti yang ditunjukkan dalam model, perlindungan teknis, prosedur transaksi, pernyataan keamanan, dan pengalaman pribadi dengan Sistem Pembayaran Elektronik adalah faktor utama untuk persepsi konsumen tentang keamanan dan kepercayaan dalam penggunaan Sistem Pembayaran Elektronik. Faktor-faktor ini diyakini memiliki pengaruh yang signifikan terhadap keamanan dan kepercayaan konsumen terhadap Sistem Pembayaran Elektronik.

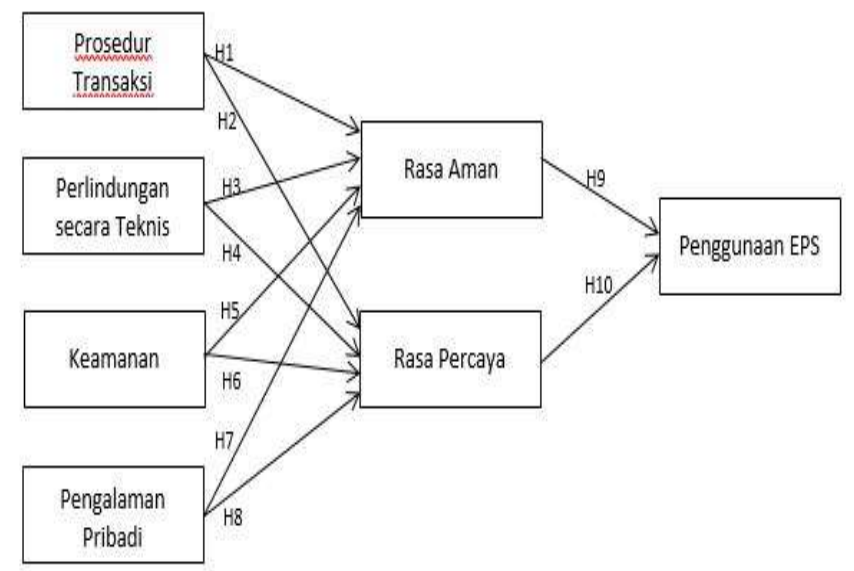

Gambar 1. Model konseptual keamanan yang dirasakan dan kepercayaan yang dirasakan dalam penggunaan Sistem Pembayaran Elektronik.

\section{B. Prosedur Transaksi}

Transaksi yang terdefinisi dengan baik prosedur membantu individu untuk menghilangkan masalah keamanan mereka [26]. Umumnya, tiga utama prosedur transaksi digunakan selama transaksi moneter elektronik. Ini prosedurnya adalah: (1) mengesahkan setiap peserta sebelum transaksi; (2) menyediakan konsumen dengan beberapa langkah terpisah menuju penyelesaian pembayaran; (3) mengirim pesan pengakuan kepada setiap peserta setelah selesainya pembayaran [26]. Pada intinya, prosedur transaksi sangat penting bagi individu untuk dapat menggunakan sistem pembayaran elektronik dengan aman dan efisien. Berdasarkan teori diatas, dapat dihipotesakan sebagai berikut:

Hipotesis 1. Prosedur transaksi memiliki peran penting dan dampak positif terhadap rasa aman konsumen.

Hipotesis 2. Prosedur transaksi memiliki peran penting dan dampak positif terhadap rasa percaya konsumen.

\section{Perlindungan Teknis}

Banyak perlindungan secara teknis telah dikembangkan dan digunakan secara berurutan untuk memastikan keamanan pembayaran elektronik [27]. Perlindungan teknis (termasuk privasi, integritas dan stabilitas) memiliki efek positif pada keamanan dan kepercayaan yang dirasakan. Berdasarkan teori diatas, dapat dihipotesakan sebagai berikut:

Hipotesis 3. Perlindungan secara teknis memiliki peran penting dan dampak positif terhadap rasa aman konsumen.

Hipotesis 4. Perlindungan secara teknis memiliki peran penting dan dampak positif terhadap rasa percaya konsumen.

\section{Keamanan}

Keamanan pada Sistem Pembayaran Elektronik menjadi faktor penting yang mempengaruhi konsumen kepercayaan yang dirasakan dalam bertransaksi [28]. Pernyataan keamanan diposting di Sistem Pembayaran Elektronik akan meningkatkan kemungkinan pembelian konsumen melalui Internet. Berdasarkan teori diatas, dapat dihipotesakan sebagai berikut:

Hipotesis 5. Keamanan memiliki peran penting dan dampak positif terhadap rasa aman konsumen.

Hipotesis 6. Keamanan memiliki peran penting dan dampak positif terhadap rasa percaya konsumen.

\section{E. Pengalaman Pribadi}

Hackbarth, Grover, dan Yi (2003) menyebutkan bahwa seseorang lebih nyaman menggunakan inovasi teknologi baru ketika mereka memiliki pengalaman sebelumnya. Alasan ini terjadi karena pengalaman masa lalu membangun kepercayaan (Eastin,2002) dan berhubungan negatif dengan adanya kekhawatiran mengenai keamanan e-commerce (Miyazaki \& Fernandez, 2001). Berdasarkan teori diatas, dapat dihipotesakan sebagai berikut:

Hipotesis 7. Pengalaman dengan sistem pembayaran elektronik memiliki peran penting dan dampak positif terhadap rasa aman konsumen.

Hipotesis 8. Pengalaman dengan sistem pembayaran elektronik memiliki peran penting dan dampak positif terhadap rasa percaya konsumen.

\section{F. Rasa Aman}

Keamanan yang dirasakan sebagai evaluasi subyektif konsumen keamanan sistem pembayaran elektronik. Konsumen dapat menganalisis dan menilai keamanan Sistem Pembayaran Elektronik secara berbeda, sehingga keamanan Sistem Pembayaran Elektronik yang dirasakan dapat berbeda antar individu [28]. Tingkat keamanan yang dirasakan memiliki dampak besar pada keputusan konsumen untuk penggunaan Sistem Pembayaran Elektronik. Jika tingkat keamanan yang dirasakan dalam Sistem Pembayaran Elektronik terlalu rendah, konsumen tidak mungkin terlibat dalam suatu transaksi [28]. Berdasarkan teori diatas, dapat dihipotesakan sebagai berikut:

Hipotesis 9. Rasa aman dalam penggunaan sistem pembayaran elektronik memiliki peran penting dan dampak 
positif terhadap konsumen untuk menggunakan sistem pembayaran elektronik.

\section{G. Rasa Percaya}

Kepercayaan telah diidentifikasi sebagai salah satu faktor paling penting yang mempengaruhi konsumen dalam penggunaan Sistem Pembayaran Elektronik dan konsumen dengan tingkat kepercayaan yang lebih tinggi telah ditemukan akan lebih terdorong untuk menggunakan Sistem Pembayaran Elektronik [28]. Tidak mungkin bagi Sistem Pembayaran Elektronik untuk mendapatkan konsumer tanpa kepercayaan [28]. Selanjutnya, telah ditemukan bahwa kepercayaan lebih penting daripada keamanan dan tanpa kepercayaan, konsumen tidak akan menggunakan Sistem Pembayaran Elektronik untuk menyelesaikan transaksi mereka. Berdasarkan teori diatas, dapat dihipotesakan sebagai berikut:

Hipotesis 10. Rasa Percaya dalam penggunaan sistem pembayaran elektronik memiliki peran penting dan dampak positif terhadap konsumen untuk menggunakan sistem pembayaran elektronik.

\section{ANALISIS DATA}

\section{A. Mengumpulkan data dan Profil}

Data yang dikumpulkan berupa kuisioner yang telah disebar, data dikumpulkan dari sampel 110 responden. Kuesioner terstruktur, berbasis google form digunakan untuk pengumpulan data. Responden hanya dapat mengisi kuesioner satu kali untuk satu akun google untuk mendapatkan hasil yang diinginkan. Sampel akhir terdiri dari 58 laki-laki dan 52 perempuan dengan rata-rata usia 20 sampai 30 tahun, Responden sebagian besar berasal dari Jakarta dengan angka responden mencapai 77 (70\%), dan responden rata-rata merupakan pelajar atau mahasiswa.

\section{B. Menilai atau Mengukur}

Perlindungan teknis (6 item), prosedur transaksi (6 item), pernyataan keamanan (6 item), kepercayaan yang dirasakan

(4 item), keamanan yang dirasakan (4 item) dan penggunaan Sistem Pembayaran Elektronik (3 item) adalah diukur dengan skala yangPengalaman pribadi dengan Sistem Pembayaran Elektronik adalah diukur dengan (5 item), yang diambil dari. Kategori respons adalah 1 dari 7 dimana 1 melambangkan sangat tidak setuju sampai di angka 7 yang melambangkan sangat amat setuju. Penelitian ini mengukur perlindungan teknis melalui privasi; integritas; dan kerahasiaan; prosedur transaksi melalui otentikasi; modifikasi; dan konfirmasi dan pernyataan keamanan melalui ketersediaan; aksesibilitas; dan komprehensibilitas [28].

\section{Statistik Deskriptif}

Perhitungan seluruh data yang telah dikumpulkan dan akan disajikan dalam bentuk tabel maupun diagram.

\section{Analisis Data}

Metode yang dilakukan dalam menganalisis data adalah Confirmatory Factor Analysis (CFA) dan Structural Equation Modelling (SEM). Metode ini digunakan dalam penelitian [29]. CFA digunakan untuk menilai kualitas pengukuran keseluruhan dan menggunakan SEM melalui AMOS 21 untuk pengujian hipotesis yang diajukan [30].

\section{E. Confirmatory Factor Analysis}

Confirmatory Factor Analysis merupakan salah satu dari dua pendekatan utama di dalam analisis faktor. Model CFA adalah metode dengan model dibentuk lebih dahulu, jumlah variabel laten ditentukan terlebih dahulu serta memerlukan identifikasi parameter [31].

TABEL 1.

DESCRIPTIVE STATICS OF THE CONSTRUCT UNDER STUDY $(\mathrm{N}=110)$

\begin{tabular}{|l|c|c|}
\hline \multicolumn{3}{|c|}{ Descriptive Statistics } \\
\hline & Mean & $\begin{array}{c}\text { Standard } \\
\text { Deviation }\end{array}$ \\
\hline ProsedurTransaksi & 4.31 & 0.61 \\
\hline PerlindunganTeknis & 4.03 & 0.63 \\
\hline PernyataanKeamanan & 4.04 & 0.64 \\
\hline PengalamanPribadi & 3.81 & 0.79 \\
\hline KeamananYangDirasakan & 3.80 & 0.75 \\
\hline KepercayaanYangDIrasakan & 3.89 & 0.85 \\
\hline PenggunaanSPE & 3.88 & 0.84 \\
\hline
\end{tabular}

Berdasarkan analisis dari Confirmatory Factor Analysis (CFA) items akan dihilangkan karena kapasitas yang rendah yaitu kurang dari 0.5 atau yang lebih significant $(\mathrm{p}>0.5)$. Dengan kata lain satu item dari masing-masing kategori prosedur transaksi, perlindungan teknis, pernyataan keamanan, pengalaman pribadi, keamanan yang dirasakan dan kepercayaan yang dirasakan akan dihilangkan. Item nya akan dihilangkan dipenelitian kedepannya, tapi dari data dalam penelitian ini dimana seluruh kategori memiliki nilai 0.5 maka seluruh kategori memenuhi syarat untuk penelitian selanjutnya.

Rata-rata nilai rata-rata yang dirangkum dan standar deviasi yang sesuai dari semua konstruksi dalam penelitian ini disajikan pada Tabel 1. Sepanjang skala pengukuran 7-point, rata-rata yang dilaporkan dari nilai penggunaan Sistem Pembayaran Elektronik adalah 3.878, menunjukkan bahwa dari sampel yang diambil pengguna dari Sistem Pembayaran Elektronik masih dibawah dari setengah total responden. Dari data diatas juga menunjukan masih minimnya penggunaan dari Sistem Pembayaran Elektronik.

Keamanan dan kepercayaan dalam Sistem Pembayaran Elektronik (masing-masing 3.89 dan 3.88) masih dikatakan rendah, dengan salah satu faktor penyababnya adalah banyak ancaman di internet bagi pengguna. Akhirnya, sepanjang 
skala pengukuran 7-point, skor pengalaman pribadi masa lalu rata-rata adalah 3.81, menunjukkan bahwa responden memiliki pengalaman, pengetahuan dan informasi tentang Sistem Pembayaran Elektronik yang masih dikatakan minim.

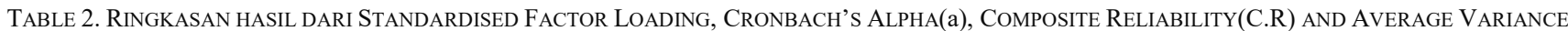
EXPLAINED (A.V.E)(N=110)

\begin{tabular}{|c|c|c|c|c|c|c|c|}
\hline INDICATOR & ProsTran & PerTek & PerKe & PengPri & ManKan & PerKan & PengSPE \\
\hline ProsTan1 & 0.71 & & & & & & \\
\hline ProsTan2 & 0.79 & & & & & & \\
\hline ProsTan3 & 0.78 & & & & & & \\
\hline ProsTan4 & 0.77 & & & & & & \\
\hline ProsTan5 & 0.84 & & & & & & \\
\hline ProsTan6 & 0.76 & & & & & & \\
\hline PerTek1 & & 0.74 & & & & & \\
\hline PerTek2 & & 0.80 & & & & & \\
\hline PerTek3 & & 0.77 & & & & & \\
\hline PerTek4 & & 0.82 & & & & & \\
\hline PerTek5 & & 0.76 & & & & & \\
\hline PerKe1 & & & 0.80 & & & & \\
\hline PerKe2 & & & 0.71 & & & & \\
\hline PerKe4 & & & 0.80 & & & & \\
\hline PerKe5 & & & 0.81 & & & & \\
\hline PerKe6 & & & 0.80 & & & & \\
\hline PengPril & & & & 0.86 & & & \\
\hline PengPri2 & & & & 0.89 & & & \\
\hline PengPri3 & & & & 0.85 & & & \\
\hline PengPri4 & & & & 0.81 & & & \\
\hline ManKan2 & & & & & 0.93 & & \\
\hline ManKan3 & & & & & 0.91 & & \\
\hline ManKan4 & & & & & 0.84 & & \\
\hline PerKan1 & & & & & & 0.75 & \\
\hline PerKan2 & & & & & & 0.89 & \\
\hline PerKan3 & & & & & & 0.91 & \\
\hline PerKan4 & & & & & & 0.86 & \\
\hline PerKan5 & & & & & & 0.87 & \\
\hline PengSPE1 & & & & & & & 0.87 \\
\hline PengSPE2 & & & & & & & 0.94 \\
\hline PengSPE3 & & & & & & & 0.78 \\
\hline Alpha () & 0.87 & 0.84 & 0.84 & 0.88 & 0.87 & 0.91 & 0.83 \\
\hline
\end{tabular}

Seperti dijelaskan di tabel 2 seluruh standar kapasitas berkisar antara 0.71 hingga 0.94 untuk seluruh items. CFA menentukan bahwa prosedur transaksi, perlindungan teknis, pernyataan keamanan, pengalaman pribadi, keamanan yang dirasakan dan kepercayaan yang dirasakan adalah variabel yang berbeda.
Solusi komponen awal diputar dengan menggunakan prosedur varimax, dengan komponen yang nilai Eigen-nya lebih besar dari satu, yang merupakan kriteria untuk retensi faktor. Berdasarkan nilai Eigen yang lebih besar dari satu, tujuh faktor diterima sebagai faktor yang dapat diinterpretasi. 
Hair, Anderson, Tatham, dan Black (2007) menunjukkan bahwa nilai lebih dari 0,50 dapat diterima untuk AVE. Jika nilai AVE kurang dari 0.50, varians karena kesalahan pengukuran melebihi varians yang ditangkap oleh konstruk; dalam kasus seperti itu validitas instrumen dapat dipertanyakan. Sesuai dengan tabel 2 bahwa nilai AVE melebihi 0.5 yang dapat dikatakan sebagai arti dari valid.

Selanjutnya, Composite reliability (CR) dari masingmasing variabel yang diperiksa. Pengukuran Composite reliability (CR) digunakan untuk memeriksa seberapa baik konstruk ditangkap oleh indikator yang ditugaskan (Hair et al., 2010). Hair et al. (2007) menunjukkan bahwa nilai lebih dari 0,70 yang dapat diterima dari reliabilitas komposit. Dari tabel 2 dapat dijelaskan bahwa nilai CR melebihi 0.7 dengan nilai yang berkisar antara 0.88 hingga 0.93 .

Karena, tidak ada masalah khusus yang terdeteksi dalam model pengukuran, pemodelan persamaan struktural kemudian digunakan untuk memeriksa kecocokan keseluruhan dari model yang diusulkan, dan untuk menilai semua koefisien jalur yang relevan. Sehingga dalam pengujian dapat dikatakan merupakan variabel yang valid dan relevan.

\section{F. Structural Equation Modelling (SEM)}

Analisis SEM menggabungkan analisis regresi, faktor, dan jalur sehingga secara simultan menghitung hubungan yang terjadi antara variabel laten, mengukur nilai loading dari indikatorindikator variabel laten, dan menghitung model jalur dari variabel-variabel laten tersebut. Pada dasarnya, SEM (Structural Equation Model) adalah salah satu teknik multivariat yang akan menunjukkan bagaimana cara merepresentasikan suatu seri atau deret hubungan kausal (causal relationship) dalam suatu diagram jalur (path diagram) [32].

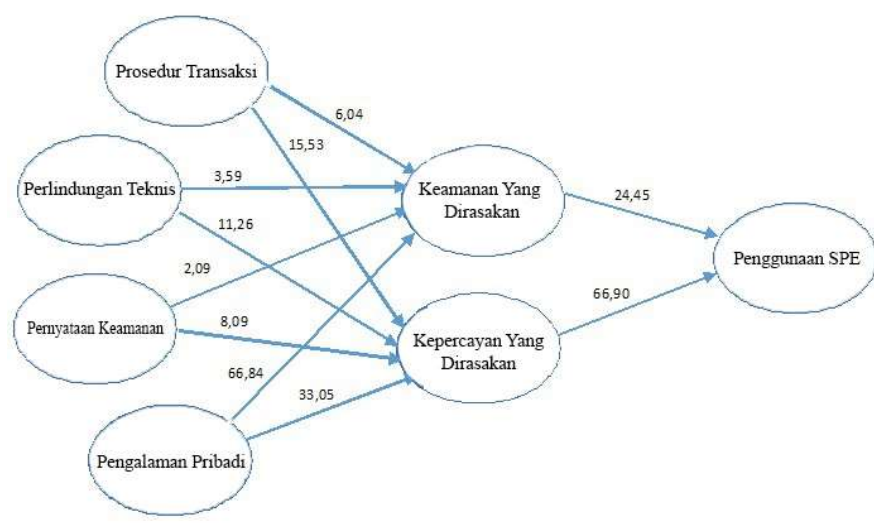

Gambar 2. Structural Equation Modelling (SEM)
TABEL 3.

T STATISTICS

\begin{tabular}{|r|c|}
\hline INDICATOR & $\begin{array}{c}\mathrm{T} \\
\text { Statistics }\end{array}$ \\
\hline ProsedurTransaksi -> KeamananYangDirasakan & 6.04 \\
\hline ProsedurTransaksi -> KepercayaanYangDirasakan & 15.33 \\
\hline PerlindunganTeknis -> KeamananYangDirasakan & 3.59 \\
\hline PerlindunganTeknis -> KepercayaanYangDirasakan & 11.26 \\
\hline PernyataanKeamanan -> KeamananYangDirasakan & 2.09 \\
\hline PernyataanKeamanan -> KepercayaanYangDirasakan & 8.09 \\
\hline PengalamanPribadi -> KeamananYangDirasakan & 66.84 \\
\hline PengalamanPribadi -> KepercayaanYangDirasakan & 33.05 \\
\hline KeamananYangDirasakan -> PenggunaanSPE & 24.45 \\
\hline KepercayaanYangDirasakan -> PenggunaanSPE & 66.90 \\
\hline
\end{tabular}

Variabel dapat dikatakan berpengaruh signifikan jika memiliki $\mathrm{t}$ hitung besar dari $\mathrm{t}$ value yaitu 1,96. Maka kesimpulan dari masing-masing hipotesis adalah sebagai berikut :

1. Prosedur Transaksi berpengaruh terhadap Keamanan Yang Dirasakan

6,04>1,96, maka Hal diterima dan H01 ditolak.

2. Prosedur Transaksi berpengaruh terhadap Kepercayaan Yang Dirasakan

x15,33> 1,96 maka Ha2 diterima dan H02 ditolak.

3. Perlindungan Teknis berpengaruh terhadap Keamanan Yang Dirasakan

3,59>1,96, maka Ha3 diterima dan $\mathrm{H} 03$ ditolak.

4. Perlindungan Teknis berpengaruh terhadap Kepercayaan Yang Dirasakan

11,26 > 1,96 maka Ha4 diterima dan H04 ditolak.

5. Pernyataan Keamanan berpengaruh terhadap

Keamanan Yang Dirasakan

2,09>1,96, maka Ha5 diterima dan H05 ditolak.

6. Pernyataan Keamanan berpengaruh terhadap

Kepercayaan Yang Dirasakan

8,09> 1,96 maka Ha6 diterima dan H06 ditolak.

7. Pengalaman Pribadi berpengaruh terhadap

Keamanan Yang Dirasakan

$66,83>1,96$, maka Ha7 diterima dan $\mathrm{H} 07$ ditolak.

8. Pengalaman Pribadi berpengaruh terhadap

Kepercayaan Yang Dirasakan

33,05 > 1,96 maka Ha7 diterima dan H07 ditolak.

9. Keamanan Yang Dirasakan berpengaruh terhadap Penggunaan SPE

24,45 > 1,96, maka Ha5 diterima dan H05 ditolak.

10. Kepercayaan Yang Dirasakan berpengaruh terhadap

Penggunaan SPE

66,90 > 1,96 maka Ha6 diterima dan H06 ditolak. 
Temuan-temuan ini telah mengungkapkan bahwa keamanan yang dirasakan dan kepercayaan yang dirasakan dapat menjadi pemicu penting dari penggunaan Sistem Pembayaran Elektronik. Hasilnya menunjukkan bahwa baik perlindungan teknis dan pengalaman masa lalu dengan ESP adalah penentu utama keamanan yang dirasakan dan kepercayaan yang dirasakan mewakili $\mathrm{H} 1$ sampai $\mathrm{H} 8$ dan pada gilirannya baik dirasakan keamanan dan kepercayaan yang dirasakan mempengaruhi penggunaan Sistem Pembayaran Elektronik mewakili H9 dan H10.

Meskipun hasil ini tidak dikonfirmasi karena hipotesisnya, itu bukan di luar pemahaman juga. Karena keamanan dan kepercayaan yang dirasakan berbeda secara konseptual, yang pertama didasarkan pada evaluasi subjektif dan yang terakhir pada keyakinan yang merumuskan harapan tertentu, oleh karena itu pernyataan keamanan berguna untuk mempengaruhi hanya evaluasi subyektif daripada membentuk keyakinan tertentu. Akhirnya, hasil telah menunjukkan bahwa baik kepercayaan yang dirasakan dan keamanan yang dirasakan memiliki pengaruh yang signifikan terhadap penggunaan. Pengaruh kepercayaan yang dirasakan telah ditemukan menjadi lebih kuat daripada persepsi keamanan pada penggunaan Sistem Pembayaran Elektronik yang disorot dalam hasil sebagai koefisien regresi kepercayaan yang dirasakan lebih tinggi dari persepsi keamanan (H9 dan H10).

\section{KESIMPULAN}

Penelitian ini mengusulkan dan menguji model penelitian yang menyelidiki faktor-faktor penentu keamanan dan kepercayaan yang dirasakan dan efek dari kedua variabel pada penggunaan Sistem Pembayaran Elektronik. Konsep keamanan dan kepercayaan telah diperiksa dari sudut pandang pengguna Sistem Pembayran Elektronik untuk memberikan pemahaman yang lebih dalam tentang konstruksi ini karena menyoroti wawasan luas dari pengguna Sistem Pembayaran Elektronik.

Hasilnya menunjukkan bahwa baik perlindungan teknis dan pengalaman pribadi merupakan faktor penentu penting dari keamanan dan kepercayaan yang dirasakan. Bersamaan dengan itu, pernyataan keamanan diidentifikasi sebagai penentu keamanan yang dirasakan. Akhirnya, dan yang paling penting, keamanan yang dirasakan dan kepercayaan yang dirasakan telah ditemukan sebagai penentu penting dari penggunaan Sistem Pembayaran Elektronik pada aplikasi Tokopedia

\section{DAFTAR PUStaka}

C. I. Hendy, "Pengembangan Aplikasi CMS E-commerce dengan PHP-CI untuk Mempermudah Penjualan dan Pembayaran Online," vol. 4, no. 1, pp. 115-122, 2016.

[2] G. S. Budhi, "Analisis Sistem E-Commerce Pada Perusahan Jual-Beli Online Lazada Indonesia," J. Electron. Informatics, Vocat. Educ., vol. 1, no. 2, pp. 78-82, 2016.
[3] I. K. D, "Perlindungan Hukum Bagi Pelaku Usaha dan Konsumen Dalam Transaksi Jual Beli Secara Online Denfan Pembayaran Melalui Paypal," E-Journal Grad. Unpar, vol. 1, no. 2, pp. 48-53, 2014.

[4] M. M. Belalawe, "Tinjauan Keamanan Sistem Transaksi dan Pembayaran pada E-Commerce Studi Kasus Toko Online," Tinj. Keamanan Sist. Transaksi dan Pembayaran pada E-Commerce Stud. Kasus Toko Online, vol. 2013, no. Sentika, pp. 1-6, 2013.

[5] F. Ramadhan and I. M. Jatra, "Pengaruh Impulsse Buying Dan Frekuensi Kunjungan Terhadap niat Pembelian Pada Situs Tokopedia di Kota Denpasar," vol. 7, no. 2, pp. 759 783, 2018.

[6] Z. Bezhovski, "The Future of the Mobile Payment as Electronic Payment System," Eur. J. Bus. Manag., vol. 8, no. 8, pp. 2222-2839, 2016.

[7] S. A. Ningrum, A. Kusyanti, and H. Aryadita, "Analisis Pengaruh Kepercayaan dan Resiko Konsumen terhadap Niat Berbelanja di Forum Jual Beli ( FJB ) Kaskus menggunakan Technology Acceptance Model," vol. 2, no. 2, pp. 459-468, 2018.

[8] K. Kaur and A. Pathak, "E-Payment System on ECommerce in India," Int. J. Eng. Res. Appl., vol. 5, no. 2, pp. 79-87, 2015.

[9] D. Y. Prasetyo, "Peranan Website Ecommerce Guna Meningkatkan Perekonomian Di Wilayah Perbatasan ( Studi Kasus Pada Umkm Di," Selondang Mayang, pp. 1-8, 2016.

[10] S. O. Talib, "E-Commerce Laws And Regulations In India," vol. 3, no. 4, pp. 66-67, 2016.

[11] J. Bernadi, "Aplikasi Sistem Informasi Penjualan Berbasis Web Pada Toko Velg YQ," ComTech, vol. 4, no. 2, pp. 731-741, 2013.

[12] A. Afsar, Z. Nasiri, and M. O. Z. Ph.D, "E-loyalty Model in e-Commerce,” Mediterr. J. Soc. Sci., vol. 4, no. 9, pp. $547-$ $553,2013$.

[13] K. C. Laudon and C. G. Traver, "E-commerce: Business, Technology, Society," Prentice-Hall, Inc., 2013.

[14] H. Xiaohui, G., Rong, G., \& JianYu, W. Chongning, "Key Technology of Distributed E-Commerce System Architecture," Telkomnika Indones. J. Electr. Eng., vol. 12, no. 5, pp. 3987-3993, 2014.

[15] J. Li, H., \& Hong, "Factors Influencing Consumers' Online Repurchasing Behavior: A Review and Research Agenda," iBusiness, vol. 5, no. 4, pp. 161-166, 2013.

[16] S. Kosasi, "Perancangan Sistem E-Commerce Untuk Memperluas Pasar Produk Oleh-Oleh Khas Pontianak," Snastia, vol. 2015, no. Oktober, pp. 110-119, 2015.

[17] H. Mulyasari, T. Thi, B. Dan, A. Bima, and M. Wijaya, "Analisis Jenis Sistem Pembayaran Elektronik Dalam Transaksi E-Commerce Di Indonesia," Semin. Nas. Teknol. Inf. dan Komun., pp. 166-173, 2014.

[18] C. R. Garg, "Importance of E-Commerce Payment System in Less Paper Work," vol. 2, no. 11, pp. 47-59, 2016.

[19] R. Y. Endra and D. Hermawan, "Fakultas Ilmu Komputer," J. Sist. Inf. Telemat. (Tellekomunikasi, Multimedia, Inform., vol. 8, no. 2, pp. 167-180, 2017.

[20] K. Widyastuti, P. W. Handayani, and I. Wilarso, "Tantangan Dan Hambatan Implementasi Produk Uang Elektronik Di Indonesia: Studi Kasus Pt Xyz," J. Sist. Inf., vol. 13, no. 1, pp. 38-48, 2017.

[21] Y. A. P, M. . Mudjahidin, S.T., and M. K. Retno Aulia Vinarti, S.Kom., "Analisis Kepercayaan Pelanggan pada E- 
Commerce Menggunakan Metode Structural Equation Modeling (Studi Kasus: Mahasiswa Surabaya)," J. Tek. POMITS, vol. 2, no. 1, pp. 1-6, 2013.

[22] M. M. Efendi and D. Trijoyo, "Analisis Faktor Konfirmatori untuk Mengetahui Kesadaran Berlalu Lintas Pengendara Sepeda Motor di Surabaya Timur," J. Sains Dan Seni Its, vol. 1, no. 1, pp. D106-D111, 2012.

[23] N. I. Sari and J. D. T. P, "Confirmatory Factor Analysis untuk Mengukur Unidimensional Indikator Performa Pengelolaan Lingkungan Hidup dalam Survei Publik Otonomi Award Jawa Pos Institute Of Pro Otonomi Tahun 2011," vol. 1, no. 1, pp. 1-7, 2012.

[24] M. Anggraeni and M. S. Perdhana, "Kepuasan Kerja, Komitmen Organisasi dan Turnover Intention di PT. Hillconjaya Sakti, Cakung, Jakarta Timur," vol. 5, no. 2011, pp. 1-10, 2012.

[25] E. Oney, G. O. Guven, and W. H. Rizvi, "The determinants of electronic payment systems usage from consumers' perspective," Econ. Res. Istraz., vol. 30, no. 1, pp. 394-415, 2017.

[26] R. J. Hwang, S. H. Shiau, and D. F. Jan, "A new mobile payment scheme for roaming services," Electron. Commer. Res. Appl., vol. 6, pp. 184-191, 2007.

[27] K. Linck, K. Pousttchi, and D. G. Wiedemann, "Security issues in mobile payment from the customer viewpoint. Proceedings of the 14th European Conference on Information Systems," ecis, vol. 14, pp. 1-11, 2006.

[28] C. Kim, W. Tao, N. Shin, and K. S. Kim, "An empirical study of customers' perceptions of security and trust in epayment systems.," Electron. Commer. Res. Appl., vol. 9, pp. 84-95, 2010.

[29] J. C. Anderson and D. W. Gerbing, "Structural equation modelling in practice: A review and recommended two steps," Psychol. Bull., vol. 103, pp. 411-423, 1988.

[30] K. G. Jöreskog and D. Sörborn, Lisrel 8: User's reerence guide. Chicago: Scientific Software, 1996.

[31] S. H. Wijanto, Structural Equation Modeling Dengan Lisrel 8.8. Yogyakarta: Graha Ilmu, 2008.

[32] R. Widiyasari and Mutiarani, "Penggunaan metode structural equation modelling untuk analisis faktor yang mempengaruhi motivasi belajar mahasiswa fip umj," Fibonacci J. Pendidik. Mat. dan Mat., vol. 3, no. 2, pp. 147-160, 2017. 